\title{
Influence of the Robotic Milking System on Milk Production and Quality: Systematic Review
}

\author{
Rodrigo Chaves Barcellos Grazziotin (Corresponding author) \\ Department of Animal Science, Universidade Federal de Pelotas, Campus Universitário \\ 96010-610, Capão do Leão-RS, Brasil \\ Tel: +55 (53) 3275-7274 E-mail: r_cbg@ hotmail.com
}

\begin{abstract}
Fernando Rutz
Department of Animal Science, Universidade Federal de Pelotas, Campus Universitário 96010-610, Capão do Leão-RS, Brasil

Tel: +55 (53) 3275-7274

Daniel José Cavalli Vieira

Department of Animal Science, Universidade Federal de Pelotas, Campus Universitário 96010-610, Capão do Leão-RS, Brasil

Tel: +55 (53) 3275-7274
\end{abstract}

Vitoria Mendonça da Silva

Department of Animal Science, Universidade Federal de Pelotas, Campus Universitário 96010-610, Capão do Leão-RS, Brasil

Tel: +55 (53) 3275-7274

\section{Rodrigo Garavaglia Chiesini}

Department of Animal Science, Universidade Federal de Pelotas, Campus Universitário 96010-610, Capão do Leão-RS, Brasil

Tel: +55 (53) 3275-7274

\section{Julio Viégas}

Department of Animal Science, Universidade Federal de Santa Maria, Campus 
Universitário 1000, Camobi, Santa Maria-RS, Brasil

Tel: +55 (55) 3220-8083

\author{
Rogério Folha Bermudes \\ Department of Animal Science, Universidade Federal de Pelotas, Campus Universitário \\ 96010-610, Capão do Leão-RS, Brasil \\ Tel: +55 (53) 3275-7274
}

Received: January 4, 2022 Accepted: February 3, 2022 Published: February 5, 2022

doi:10.5296/jas.v10i1.19116

URL: https://doi.org/10.5296/jas.v10i1.19116

\begin{abstract}
This review aims to report the direct influence of a robotic milking system (RMS) on milk production and quality. The Scopus, SciELO, and Web of Science platforms were used as search databases. We followed the PRISMA protocol for the identification and screening of articles. Initially, 336 articles were identified. We excluded 186 articles for duplicity, 53 after screening abstracts and titles, 20 for lack of access, and 58 articles based on the exclusion criteria. Nineteen articles from 2002 to 2021 from 10 different journals were selected. We observed an increase in publications related to RMS in recent years, and the Journal of Dairy Science gained prominence among the journals whose articles were used in the present study. After lexicographic analysis of abstracts, it was clear that there were five predominant classes, and the keyword RMS was more associated with factors related to cows than milk. The study results contribute to a greater understanding of RMS research, providing farmers and readers with clarification on the actual influences on the dairy chain system and future research projects.
\end{abstract}

Keywords: milking, productivity, herd, health

\title{
1. Introduction
}

The robotic milking system (RMS) has represented one of the most remarkable advances in milk production techniques since the $90 \mathrm{~s}$, with rapid adherence by all livestock farmers in this area worldwide. By 2020, approximately 50,000 operating units were estimated to exist on the planet (Filho et al., 2020), located mainly in Europe and Canada (Cogato et al., 2021).

These systems have been popularized as they potentially provide more quality for workers, reducing labor and time effort compared to conventional milking systems. These systems also promise to optimize milk production rates, quality, and mammary gland health (Hovinen \& Pyörälä, 2011; Rodenburg, 2017; Hogenboom et al., 2019). Thus, some improvement in milk production by direct or indirect routes is unquestionable, given the growth of adherence to technology in recent decades. 


\section{Mll Macrothink}

The significant difference in the system is the voluntary access of cows to the milking unit during lactation, as voluntary access can generate variation in the intervals between milking. This variation is higher in animals subjected to robotic milking than in animals milked using a conventional system, which is why they can provide higher milk production (Masía et al., 2020). Nevertheless, a decrease in milking frequency from twice a day to once a day results in an immediate increase in the somatic cell count (SCC) (Stelwagen \& Lacy-Hulbert, 1996).

In robotic milking, mechanical arms perform preliminary operations such as brushing and udder sanitation. Based on the identification of the animal, the robot adapts to the morphological characteristics of the cow (height, udder size, teat shape, and angle). However, there are criteria for excluding cows from the herd to achieve an efficient acceptance of the robot. Cows considered unsuitable for the system (Córdova et al., 2018b) revealed a possible failure in the system.

Considering the disagreement among several articles for the analyses of dairy production and robotic milking, and numerous conclusions suggesting premises for new research (Wagner-Storch \& Palmer, 2003; Jacobs \& Siegford, 2012; King \& DeVries, 2018; Córdova et al., 2020), the authors noted the need for a systematic review on the robotic milking system, as well as the evaluation of qualitative aspects. Therefore, our intent was to represent the direction of published research in this area and outline a qualitative level of the studies which have been addressed.

\section{Methodology}

This article presents a systematic review conducted according to the recommendations of the PRISMA protocol. We selected the studies in the SciELO, Scopus, and Web of Science databases using the keywords "Robotic milking," "Somatic cell count," "SCC," "Total cell count," "TBC," "Milk production," and "Milk quality." We used these keywords in both Portuguese and English. The keyword "Robotic milking" was integrated into the search with other keywords using the Boolean Operator 'AND,' as described in Table 1. We opted for complete articles in journals and reviews as the initial filtering method.

Two researchers independently evaluated the studies and discussed any doubts concerning the article selection until an agreement was reached. In cases of disagreement, a third evaluator was selected to decide on the article's inclusion in this review.

This systematic review aims to report on the influence of robotic milking on milk production and quality. So, we sought to answer the guiding question formulated by the Population Variable Outcome (PVO) strategy. ${ }^{1}$ : What is the influence of robotic milking (variable) on milk production and quality (outcome) in dairy cattle (population)?

The inclusion criteria were as follows: 1) quantitative studies presented in the abstract, title, or keywords, 2) the characters "robotic milking" and the respective translation in the Portuguese language, 3) no year restrictions, and 4) publications in English, Portuguese, and Spanish. The exclusion criteria were as follows: 1) studies outside the objective, 2) qualitative studies on milk quality and production, 3) articles regarding other milking systems,

\footnotetext{
1 PVO: P (dairy cattle) V (robotic milking) O (milk production and quality).
} 
and 4) review articles, letters to editor/editorials, personal opinions, chapters of books, textbooks, reports, and conference summaries.

Table 1. Search strategy for databases

\begin{tabular}{|c|c|c|}
\hline Database & Search Strategy & Results \\
\hline \multirow{6}{*}{$\begin{array}{c}\text { SciELO } \\
\text { http://www.scielo.org/ }\end{array}$} & $\begin{array}{l}\text { (Robotic milking) AND (Milk production) } \\
\text { OR (Ordenha Robotizada) AND (Produção } \\
\text { de leite) }\end{array}$ & 6 \\
\hline & $\begin{array}{l}\text { (Robotic milking) AND (Milk quality) OR } \\
\text { (Ordenha Robotizada) AND (Qualidade do } \\
\text { leite) }\end{array}$ & 2 \\
\hline & $\begin{array}{l}\text { (Robotic milking) AND (scc) OR (Ordenha } \\
\text { Robotizada) AND (ccs) }\end{array}$ & 2 \\
\hline & $\begin{array}{l}\text { (Robotic milking) AND (somatic cells } \\
\text { count) OR (Ordenha Robotizada) AND } \\
\text { (contagem de células somáticas) }\end{array}$ & 1 \\
\hline & $\begin{array}{l}\text { (Robotic milking) AND (tbc) OR (Ordenha } \\
\text { Robotizada) AND (cbt) }\end{array}$ & 2 \\
\hline & $\begin{array}{l}\text { (Robotic milking) AND (total bacterial } \\
\text { count) OR (Ordenha Robotizada) AND } \\
\text { (contagem bacteriana total) }\end{array}$ & 0 \\
\hline \multirow{6}{*}{$\begin{array}{c}\text { Scopus } \\
\text { https://www.scopus.com/ }\end{array}$} & $\begin{array}{l}\text { (Robotic milking) AND (Milk production) } \\
\text { OR (Ordenha Robotizada) AND (Produção } \\
\text { de leite) }\end{array}$ & 66 \\
\hline & $\begin{array}{l}\text { (Robotic milking) AND (Milk quality) OR } \\
\text { (Ordenha Robotizada) AND (Qualidade do } \\
\text { leite) }\end{array}$ & 39 \\
\hline & $\begin{array}{l}\text { (Robotic milking) AND (scc) OR (Ordenha } \\
\text { Robotizada) AND (ccs) }\end{array}$ & 12 \\
\hline & $\begin{array}{l}\text { (Robotic milking) AND (somatic cells count) } \\
\text { OR (Ordenha Robotizada) AND (contagem } \\
\text { de células somáticas) }\end{array}$ & 21 \\
\hline & $\begin{array}{l}\text { (Robotic milking) AND (tbc) OR (Ordenha } \\
\text { Robotizada) AND (cbt) }\end{array}$ & 2 \\
\hline & $\begin{array}{l}\text { (Robotic milking) AND (total bacteria count) } \\
\text { OR (Ordenha Robotizada) AND (contagem } \\
\text { bacteriana total) }\end{array}$ & 4 \\
\hline \multirow{6}{*}{$\begin{array}{l}\text { Web of Science } \\
\text { http://apps. } \\
\text { webofknowledge.com/ }\end{array}$} & $\begin{array}{l}\text { (Robotic milking) AND (Milk production) } \\
\text { OR (Ordenha Robotizada) AND (Produção } \\
\text { de leite) }\end{array}$ & 83 \\
\hline & $\begin{array}{l}\text { (Robotic milking) AND (Milk quality) OR } \\
\text { (Ordenha Robotizada) AND (Qualidade do } \\
\text { leite) }\end{array}$ & 48 \\
\hline & $\begin{array}{l}\text { (Robotic milking) AND (scc) OR (Ordenha } \\
\text { Robotizada) AND (ccs) }\end{array}$ & 10 \\
\hline & $\begin{array}{l}\text { (Robotic milking) AND (somatic cells count) } \\
\text { OR (Ordenha Robotizada) AND (contagem } \\
\text { de células somáticas) }\end{array}$ & 33 \\
\hline & $\begin{array}{l}\text { (Robotic milking) AND (tbc) OR (Ordenha } \\
\text { Robotizada) AND (cbt) }\end{array}$ & 1 \\
\hline & $\begin{array}{l}\text { (Robotic milking) AND (total bacteria count) } \\
\text { OR (Ordenha Robotizada) AND (contagem } \\
\text { bacteriana total) }\end{array}$ & 4 \\
\hline TOTAL & & 336 \\
\hline
\end{tabular}




\section{Al Macrothink

After the including and excluding of articles, the remaining studies were subjected to risk and bias analyses. The list of criteria applied to each article is described in Board 1 based on the ideas established by Koutsos et al., 2019. We assumed three possible answers to the questions for each article, admitting the scale: Yes $(Y)=20$ points, Inconclusive $(\mathrm{I})=10$ points, and Not $(\mathrm{N})=0$ points(Kitchenham et al. 2009). We calculated the final score by percentages of articles that resulted in $60 \%$ or more being included in the review. The bias assessment was described by Board 2. We observed that 19 of the 25 previously defined studies reached the desirable criterion of $60 \%$, confirming the credibility of the selected studies.

Board 1. Risk of bias criteria checklist

\begin{tabular}{|c|l|}
\hline Questions & \multicolumn{1}{c|}{ Criteria } \\
\hline Q1 & Are the animals adapted to robotic milking? \\
\hline Q2 & $\begin{array}{l}\text { Was the research carried out with an adequate number of animals per } \\
\text { robot? }\end{array}$ \\
\hline Q3 & Is milk production one of the main results of the article? \\
\hline Q4 & Does this study quantitatively describe the SCC or TBC of milk? \\
\hline Q5 & Was the experiment conducted randomly? \\
\hline
\end{tabular}

The search was conducted in September 2021. The results were exported to Mendeley Desktop v. 1.19.8, Mendeley Reference Manager v. 2.54.0, and duplicates were discarded. We organized the remaining results in Microsoft Excel 2010 (Microsoft ${ }^{\mathrm{TM}}$ Ltd, Washington, USA), in which bias criterion questions were posed. After obtaining the research articles, we listed the authors, year of publication, journal, objectives, main results linked to the systematic review, and conclusions for efficient organization of the results (Table 2). 
Board 2. Bias risk assessment

\begin{tabular}{|c|c|c|c|c|c|c|}
\hline Studies & Q1 & Q2 & Q3 & Q4 & Q5 & $\%$ \\
\hline S1 & N & Y & Y & N & Y & $60 \%$ \\
S2 & Y & Y & N & N & N & $20 \%$ \\
S3 & I & I & Y & Y & Y & $80 \%$ \\
S4 & I & I & N & N & N & $20 \%$ \\
S5 & I & I & Y & Y & Y & $80 \%$ \\
S6 & I & Y & Y & Y & I & $80 \%$ \\
S7 & Y & I & Y & N & Y & $70 \%$ \\
S8 & I & I & Y & Y & Y & $80 \%$ \\
S9 & N & I & N & Y & N & $30 \%$ \\
S10 & I & Y & Y & Y & Y & $90 \%$ \\
S11 & I & Y & N & N & Y & $50 \%$ \\
S12 & Y & N & Y & N & Y & $60 \%$ \\
S13 & Y & Y & Y & N & N & $60 \%$ \\
S14 & Y & Y & Y & N & Y & $80 \%$ \\
S15 & I & I & Y & Y & N & $60 \%$ \\
S16 & I & Y & Y & N & Y & $70 \%$ \\
S17 & N & Y & Y & Y & N & $60 \%$ \\
S18 & Y & I & N & Y & I & $60 \%$ \\
S19 & I & I & N & Y & N & $40 \%$ \\
S20 & Y & Y & Y & N & Y & $80 \%$ \\
S21 & I & N & Y & N & Y & $50 \%$ \\
S22 & I & I & Y & Y & N & $60 \%$ \\
S23 & I & I & N & Y & Y & $60 \%$ \\
S24 & N & Y & Y & N & Y & $60 \%$ \\
S25 & I & I & Y & Y & I & $70 \%$ \\
\hline
\end{tabular}

The main information about the variables investigated in the selected studies was extracted for writing the results and discussion section of our review article. Therefore, the articles were analyzed specifically for the categories "milk quality" and "milk production."

The text data were also processed and submitted for lexicographic analysis using the IRAMUTEQ 0.7 alpha2 software, aiming for qualitative analysis. Texts originally written in Portuguese or Spanish were translated into English for linguistic equalization. The keyword "Robotic Milking" was separated by "_,, becoming "Robotic_Milking”, to be read by the program as a single expression, avoiding parsing errors. Therefore, we used a descending hierarchical classification and similarity analysis

\section{Results}

Based on the combinations mentioned above, searching through keywords resulted in the initial identification of 336 studies. First, 186 articles were identified. Then, 150 articles were selected to read the titles and abstracts; 53 were excluded, resulting in 97 readable articles. We did not have access to the full text of the 20 articles. In total, 77 articles were read. After applying the exclusion criteria, 19 studies that answered the guiding question of our investigation were selected (Figure 1). 


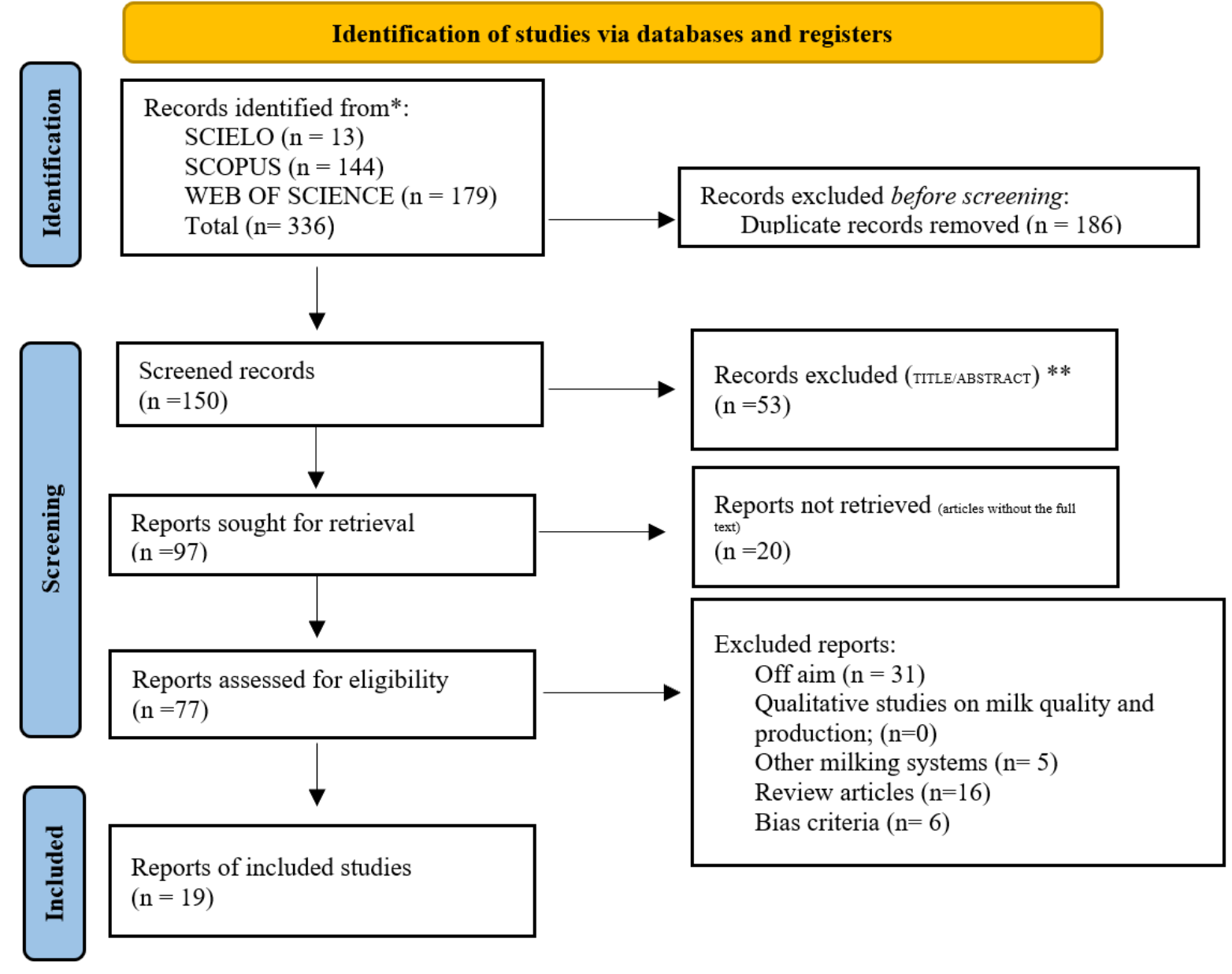

Figure 1. Identification flowchart

Source: Adapted from PRISMA 2020 statement.

The selected studies were published in 10 journals over 12 years. The main characteristics of the studies and a summary of the results are presented in Table 2. It is important to note that the main conclusions and results described here always correlate with the variables studied in our review, thus increasing the reliability and highlighting the aim of the study 
Table 2. Selected articles

\begin{tabular}{|c|c|c|c|c|c|c|c|}
\hline NUMBER & Title & Author & Year & Journal & Objective & Main results & Conclusion \\
\hline 1 & $\begin{array}{l}\text { Adaptation } \\
\text { strategy of } \\
\text { different cow } \\
\text { genotypes to the } \\
\text { voluntary milking } \\
\text { system }\end{array}$ & O.O. Borshch et. al. & 2020 & Ukrainian Journal of Ecology & $\begin{array}{l}\text { The aim was of this study } \\
\text { was to discover the } \\
\text { adaptation indicators of } \\
\text { different breeds first-calving } \\
\text { cows to voluntary (robotic) } \\
\text { milking system during the } \\
\text { first month of lactation. }\end{array}$ & $\begin{array}{l}\text { The groups of French Holstein breed } \\
\text { and Brown Swiss breed, had lower daily } \\
\text { average milk yields of these cows' } \\
\text { groups during the adaptation period, } \\
\text { compared to the German Holstein breed }\end{array}$ & 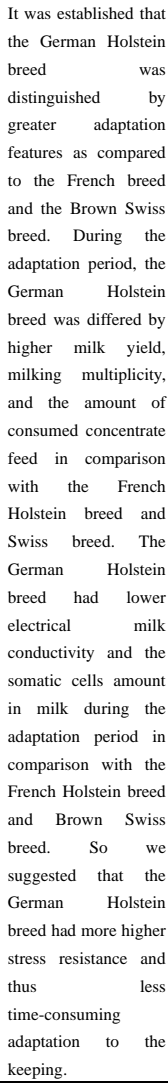 \\
\hline 2 & $\begin{array}{l}\text { Behavior, health, } \\
\text { and productivity } \\
\text { of early-lactation } \\
\text { dairy cows } \\
\text { supplemented } \\
\text { with molasses in } \\
\text { automated } \\
\text { milking systems }\end{array}$ & 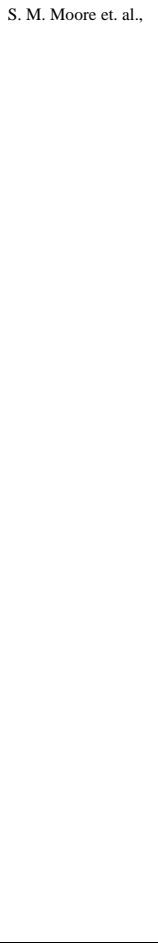 & 2020 & 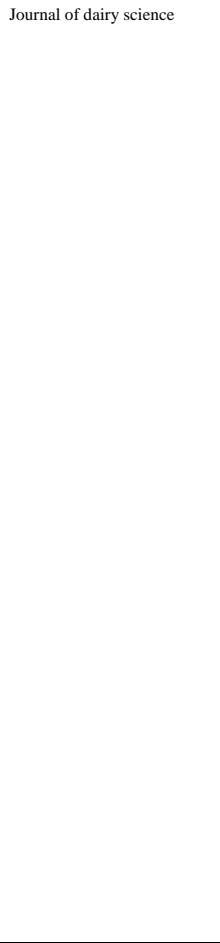 & $\begin{array}{l}\text { The objective of this study } \\
\text { was to determine the effect } \\
\text { of molasses-based liquid } \\
\text { feed (LF) supplementation } \\
\text { within automated milking } \\
\text { systems (AMS) on the } \\
\text { behavior, health, and } \\
\text { production ar a } \\
\text { early-lactation dairy cows. }\end{array}$ & $\begin{array}{l}\text { No differences were detected between } \\
\text { treatments for milk yield (average milk } \\
\text { yield }=37.4 \pm 1.98 \mathrm{~kg} / \mathrm{d} \text { ) and milking } \\
\text { frequency (average milking frequency = } \\
3.2 \pm 0.01 \text { times } / \mathrm{d} \text { ). }\end{array}$ & $\begin{array}{l}\text { Supplementing a } \\
\text { molasses-based liquid } \\
\text { feed to early-lactation } \\
\text { dairy cows milked in } \\
\text { AMS demonstrated } \\
\text { positive benefits for } \\
\text { cow metabolic health, } \\
\text { but did not affect } \\
\text { production outcomes } \\
\text { or rumination } \\
\text { behavior as } \\
\text { hypothesized Cows } \\
\text { receiving this extra } \\
\text { energy } \\
\text { supple-mentation } \\
\text { across the first } 60 \text { DIM } \\
\text { displayed lower blood } \\
\text { BHB levels by 15 } \\
\text { DIM and had fewer } \\
\text { repeat positive tests } \\
\text { for SCK. Additionally, } \\
\text { LF cows lost less body } \\
\text { condition over the first } \\
60 \text { DIM compared } \\
\text { with CON cows. } \\
\text { Therefore, } \\
\text { supplementing a } \\
\text { molasses-based liquid } \\
\text { feed to fresh cows } \\
\text { milked in AMS may } \\
\text { be an effective way to } \\
\text { supply additional } \\
\text { energy to cows during } \\
\text { a period of NEB }\end{array}$ \\
\hline 3 & $\begin{array}{l}\text { Benchmarking of } \\
\text { farms with } \\
\text { automated } \\
\text { milking systems } \\
\text { in Canada and } \\
\text { associations with } \\
\text { milk production } \\
\text { and quality }\end{array}$ & R. D. Matson et. al., & 2021 & Journal of dairy science & $\begin{array}{l}\text { The objective of this study } \\
\text { was to benchmark the } \\
\text { herd-level housing and } \\
\text { management strategies of } \\
\text { auto-mated milking system } \\
\text { (AMS) farms across Canada } \\
\text { and assess the associations } \\
\text { of these herd-level housing }\end{array}$ & $\begin{array}{l}\text { Greater lying alley width }(\mathrm{cm}) \text { was } \\
\text { associated with lower SCC; each } 30 \mathrm{~cm} \\
\text { increase in lying al-ley width tended to } \\
\text { be associated with } 10,414 \text { cells } / \mathrm{mL} \\
\text { decrease in SCC. Greater alley-cleaning } \\
\text { frequency (no./d) was associated with } \\
\text { lower SCC; each } 5 \text { additional alley } \\
\text { cleanings per day was associated with }\end{array}$ & $\begin{array}{l}\text { Specifically, when } \\
\text { controlling for breed } \\
\text { differences, AMS } \\
\text { herds with greater feed } \\
\text { push-up frequency, } \\
\text { greater feed bunk } \\
\text { space per cow, and } \\
\text { ventilation systems }\end{array}$ \\
\hline
\end{tabular}


fac-tors and management 7,012 cells $/ \mathrm{mL}$ lower SCC. Lesser other than natural practices with milk stocking density at the feed bunk ventilation alone had production and quality. $\quad(\mathrm{cm} / \mathrm{cow})$ was positively associated greater milk yield, with milk yield; each 10-cm increase in FCM, and ECM per feed bunk space per cow was associated cow. Greater milk with $+0.3 \mathrm{~kg} / \mathrm{d}$ greater milk production yield per cow and This is the first time that feed push-up lower herd-average frequency has been associated with SCC were also greater milk yield in herds with AMS. reported for those Each of these models controlled for the herds using sand effect of breed, with Holstein bedding as compared herds having $9.3 \mathrm{~kg} / \mathrm{d}$ greater milk yield with those bedding than additional 5 feed push-ups per day was substrates. associated with $0.35 \mathrm{~kg} / \mathrm{d}$ greater milk Additionally, greater yield

lying alley width and alley-cleaning

frequency were associated with lower herd-average SCC.

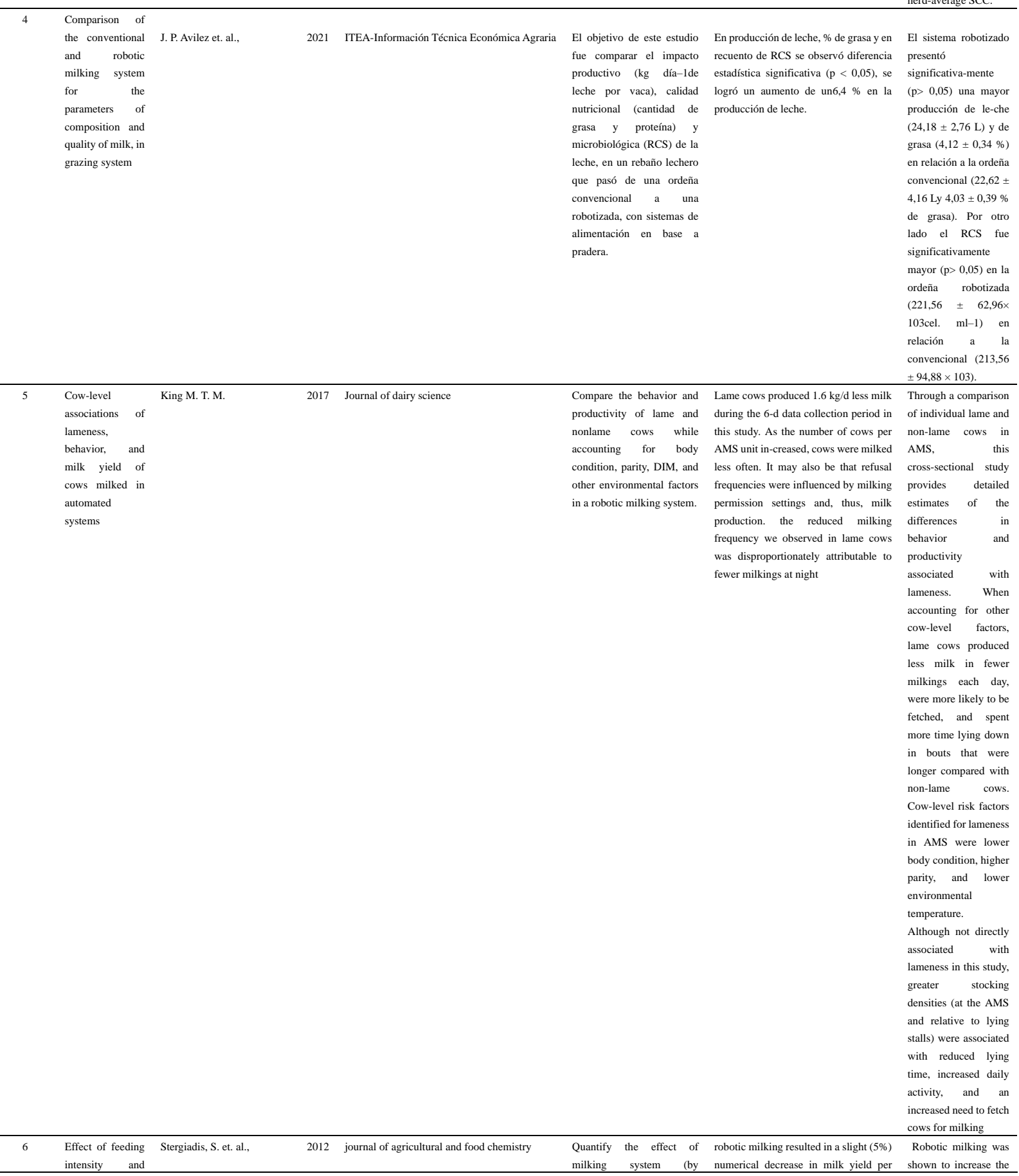


milking syste

on nutritionally

relevant milk

components in

dairy farming

systems in the

north east of

England comparing farms using cow even though it is known to increase incidence of clinical standard and robotic milking frequency and would therefore mastitis and veterinary milking systems but similar have been expected to increase milk antibiotic use.

feeding regimens) on animal yield. SCC in milk (an indictor of

health and nutritionally subclinical mastitis) were not

relevant milk composition significantly different between seasons

parameters (protein, FA, and and farms using contrasting milking

antioxidant profiles). systems.

identify associations

between specific production

system components (e.g.

dietary components,

housing, milking

system/frequency,

proportion

milking

Holstein-Friesian cows) and

milk composition by

redundancy analysis

The objective of this study No differences were detected between For primiparous cows was to determine whether treatments in the frequency of rejected in early to peak the amount of concentrate milkings per day, daily yield, yield per lactation and milked in allowance in an automated milking, box time per visit, milk fat or a free-traffic AMS milking system (AMS) protein, MUN, or SCC with low stocking affects partial mixed ration density, allocating a (PMR) sorting behavior, greater quantity of milking activity, and concentrate to the production of lactating dairy AMS and altering the cows fed isocaloric diets.

PMR to maintain total dietary nutrient density decreased the extent of PMR sorting and increased total DMI, despite lower PMR intake. Further, allocating a greater proportion of dietary concentrate to the AMS also increased voluntary AMS visits and milkings and reduced the frequency of fetching to the AMS. Despite greater day-to-day variation in AMS concentrate intake, allocating a greater amount of concentrate to the AMS resulted in decreased sorting of the PMR, with no difference day-to-day variation of PMR intake and total DM Therefore, offering a greater proportion of total dietary concentrate at the AMS in free-traffic systems with low stocking density may promote greater milking activity while maintaining

consistency in total amount of DM consumed

\begin{tabular}{|c|c|c|c|c|c|c|c|}
\hline 8 & $\begin{array}{l}\text { Effects on milk } \\
\text { yield of milking } \\
\text { interval regularity } \\
\text { and teat cup } \\
\text { attachment } \\
\text { failures with } \\
\text { robotic milking } \\
\text { systems }\end{array}$ & Bach et. al., & 2005 & Journal of Dairy Research & $\begin{array}{l}\text { Assess the impact of teat } \\
\text { cup attachment failures and } \\
\text { milking interval regularity } \\
\text { on milk production with an } \\
\text { AMS using a retrospective } \\
\text { database }\end{array}$ & $\begin{array}{l}\text { Average milk production throughout the } \\
\text { monitored period was } 14.1 \pm 5.4 \\
1 / \text { milking, with an average milking } \\
\text { interval of } 12.06 \pm 4.07 \mathrm{~h} \text {. Milk } \\
\text { production from the front quarters was } \\
60 \% \text { of the production from the rear } \\
\text { quarters ( } 5.3 \mathrm{v} .8 .8 \mathrm{~kg} / \text { milking). Average } \\
\text { somatic cell count throughout the } \\
\text { period of the study was } 262000 \pm 15.4 \\
\text { cells } / \mathrm{ml} \text {. }\end{array}$ & $\begin{array}{l}\text { Apparently, a milking } \\
\text { failure seems to affect } \\
\text { the ability of the } \\
\text { mammary gland to } \\
\text { eject milk resulting in } \\
\text { low milk flowrates. } \\
\text { However, these three } \\
\text { negative consequences } \\
\text { of milking failures are } \\
\text { transient, as milk } \\
\text { production should } \\
\text { return to the levels } \\
\text { prior to the failure } \\
\text { within seven milkings. } \\
\text { On the other hand, } \\
\text { irregular milking }\end{array}$ \\
\hline
\end{tabular}




\begin{tabular}{|c|c|c|c|c|c|c|c|}
\hline & & & & & & & $\begin{array}{l}\text { intervals represent a } \\
\text { potential problem with } \\
\text { AMS, especially when } \\
\text { the weekly CV for } \\
\text { milking intervals } \\
\text { is }>27 \% \text {. Above this } \\
\text { variation, milk } \\
\text { synthesis appears to be } \\
\text { compromised. It is, } \\
\text { therefore, important to } \\
\text { implement } \\
\text { management practices } \\
\text { that reduce the } \\
\text { irregularity of milking } \\
\text { intervals with AMS. }\end{array}$ \\
\hline 9 & $\begin{array}{l}\text { Feeding behavior, } \\
\text { milking behavior, } \\
\text { and milk yields of } \\
\text { cows milked in a } \\
\text { parlor versus an } \\
\text { automatic } \\
\text { milking system }\end{array}$ & Wagner-Storch A. M. et. al., & 2003 & Journal of dairy science & $\begin{array}{l}\text { Determine the effect on } \\
\text { milk yield of cows milked } \\
\text { with a conventional herring } \\
\text { bone milking parlor } 2 \times a n d \\
\text { cows milked in a robotic } \\
\text { milking system; }\end{array}$ & $\begin{array}{l}\text { Robot system had lower parity ( } 1.6 \mathrm{vs.} \\
2.4 \pm 0.1 \text {, higher milking frequency } \\
(2.4 \pm 0.02 \text { vs. } 2.0 \pm 0.0 \text { ), and slightly } \\
\text { higher milk production ( } 58.1 \text { vs. } \\
56.7 \pm 0.5 \mathrm{lb} \text {, or } 26.4 \mathrm{vs} .25 .8 \pm 0.2 \mathrm{~kg} \text { ) } \\
\text { than parlor cows. Lower average parity } \\
\text { of cows in the robot group was partially } \\
\text { the result of the animal selection } \\
\text { process, where cows with uneven } \\
\text { udders were assigned to the parlor side } \\
\text { to avoid robot unit attachment } \\
\text { problems. }\end{array}$ & $\begin{array}{l}\text { Because human } \\
\text { intervention increased } \\
\text { milking and feeding } \\
\text { activity for cows } \\
\text { milked with a robot, } \\
\text { studying effects on } \\
\text { milking frequency, } \\
\text { feeding activity, and } \\
\text { milk production of } \\
\text { additional human } \\
\text { intervention during the } \\
\text { night would be of } \\
\text { interest }\end{array}$ \\
\hline 10 & $\begin{array}{l}\text { Feeding soyhulls } \\
\text { to high-yielding } \\
\text { dairy cows } \\
\text { increased milk } \\
\text { production, but } \\
\text { not milking } \\
\text { frequency, in an } \\
\text { automatic } \\
\text { milking system }\end{array}$ & Halachmi, I. et. al., & 2009 & Journal of dairy science & $\begin{array}{l}\text { Quantify the effects of } \\
\text { replacing starchy grain } \\
\text { pellets with pellets high in } \\
\text { digestible NDF ( } 6 \text { to } 14 \mathrm{~kg} / \mathrm{d} \\
\text { per cow) on the AMS } \\
\text { behavior of high-yielding } \\
\text { cows and on their milk-ing } \\
\text { performance. }\end{array}$ & $\begin{array}{l}\text { The milk yield of the experimental } \\
\text { group ( } 42.7 \pm 0.76 ; 44.5 \pm 0.43 ; 39.1 \pm \\
0.33 \text { ) was higher than that of the control } \\
\text { group ( } 39.7 \pm 0.68 ; 42.4 \pm 0.45 ; 37.5 \pm \\
0.40 \text { ) throughout the lactation. }\end{array}$ & $\begin{array}{l}\text { The inclusion of SH } \\
\text { pellets high in } \\
\text { digestible NDF in } \\
\text { place of starchy grains } \\
\text { fed to high-yielding } \\
\text { dairy cows milked in } \\
\text { an AMS 1) led to more } \\
\text { milk, but not to a } \\
\text { greater frequency of } \\
\text { milking in the AMS; } \\
\text { and 2) led to an } \\
\text { increase in daily milk } \\
\text { yields from } 39.7 \text { to } \\
42.7 \mathrm{~kg} \text { at } 10 \text { to } 60 \\
\text { DIM, from } 42.4 \text { to } \\
44.4 \mathrm{~kg} \text { at } 61 \text { to } 120 \\
\text { DIM, and from } 37.54 \\
\text { to } 39.09 \mathrm{~kg} \text { at } 120 \text { to } \\
180 \text { DIM. This study } \\
\text { adds evidence } \\
\text { showing that what is } \\
\text { fed in the AMS has no } \\
\text { impact on milking } \\
\text { frequency. }\end{array}$ \\
\hline 11 & $\begin{array}{l}\text { Impact of } \\
\text { automatic } \\
\text { milking systems } \\
\text { on dairy cattle } \\
\text { producers' reports } \\
\text { of milking labour } \\
\text { management, } \\
\text { milk production } \\
\text { and milk quality }\end{array}$ & Tse, C. et. al,. & 2018 & Animal & $\begin{array}{l}\text { Determine producers' } \\
\text { reports of change in milking } \\
\text { labour management } \\
\text { (milking-related activities), } \\
\text { milk production, milk } \\
\text { quality, and use of DHI } \\
\text { programmes after transition } \\
\text { to AMS. }\end{array}$ & $\begin{array}{l}\text { Median milking frequency was } 3.0 \\
\text { milkings/cow day, with Lely owners } \\
\text { reporting higher milking frequency than } \\
\text { DeLaval owners. After adopting AMS, } \\
\text { most producers }(81 \%) \text { reported that } \\
\text { milk yield had increased. Overall, milk } \\
\text { yield on AMS farms was } 32.6 \mathrm{~kg} / \mathrm{cow} \\
\text { per day, with no differences between } \\
\text { AMS brands. Based on reported } \\
\text { averages over the past year, geometric } \\
\text { mean BTSCC was } 180000 \text { cells/ml, } \\
\text { with no differences between the two } \\
\text { predominant brands. At AMS Milk } \\
\text { yield and herd size were not associated } \\
\text { (P=0.43), whereas milk yield tended to } \\
\text { decrease with increasing number of } \\
\text { cows/robot }(\mathrm{P}=0.06) \text {. }\end{array}$ & $\begin{array}{l}\text { farms using an AMS } \\
\text { reported increased } \\
\text { milk yield with little } \\
\text { effect on milk quality. } \\
\text { The number of } \\
\text { employees and time } \\
\text { devoted to } \\
\text { milking-related } \\
\text { activities decreased } \\
\text { after the transition to } \\
\text { AMS. Half of the } \\
\text { producers who were } \\
\text { not DHI participants } \\
\text { had stopped } \\
\text { participation after } \\
\text { transitioning to AMS. } \\
\text { Findings from this } \\
\text { study can actas a } \\
\text { benchmark for future } \\
\text { dairy producers who } \\
\text { decide to switch to } \\
\text { AMS and improve } \\
\text { transitions by by } \\
\text { providing information } \\
\text { on what to expect }\end{array}$ \\
\hline 12 & $\begin{array}{l}\text { Impact of the } \\
\text { factors of animal } \\
\text { production and } \\
\text { welfare on } \\
\text { robotic milking } \\
\text { frequency }\end{array}$ & Córdova, A. H. et. al,. & 2018 & Pesquisa Agropecuaria Brasileira & $\begin{array}{l}\text { Evaluate the impact of } \\
\text { production factors on } \\
\text { milking frequency and the } \\
\text { latter's effect on animal } \\
\text { welfare in robotic milking }\end{array}$ & $\begin{array}{l}\text { The average milk yield per milking } \\
\text { varied from } 13.32 \mathrm{~kg} \text { at the beginning of } \\
\text { lactation to } 15.48 \mathrm{~kg} \text { at its peak, } \\
\text { reaching } 13.36 \mathrm{~kg} \text { at the end of } \\
\text { lactation. The curves for milk yield per } \\
\text { milking, ECM and protein production, } \\
\text { and milking frequency decreased }\end{array}$ & $\begin{array}{l}\text { The increase in } \\
\text { milking frequency } \\
\text { observed in the } \\
\text { automatic milking } \\
\text { system (AMS) is } \\
\text { affected by factors } \\
\text { such as concentrate }\end{array}$ \\
\hline
\end{tabular}




\begin{tabular}{|c|c|c|c|c|c|c|c|}
\hline & & & & & & $\begin{array}{l}\text { yield observed at } 105 \text { days of lactation } \\
\text { may have been caused by the higher } \\
\text { concentrate intake at this lactation stage } \\
\text { and the higher number of daily milkings } \\
\text { at the beginning of lactation. }\end{array}$ & $\begin{array}{l}\text { milk yield, and } \\
\text { locomotion problems. } \\
\text { Milking frequency } \\
\text { impacts milk yield and } \\
\text { protein content and, to } \\
\text { a lesser degree, fat } \\
\text { content. Milking } \\
\text { frequency does not } \\
\text { affect mammary gland } \\
\text { health or animal } \\
\text { welfare. The AMS } \\
\text { allows the } \\
\text { management of the } \\
\text { evaluated data in real } \\
\text { time, facilitating } \\
\text { decision making to } \\
\text { improve management, } \\
\text { milk yield, and animal } \\
\text { welfare. }\end{array}$ \\
\hline 13 & $\begin{array}{l}\text { Influence of } \\
\text { udder depth on } \\
\text { cleaning teats and } \\
\text { health of the } \\
\text { mammary gland } \\
\text { in robotic milking }\end{array}$ & Córdova, A. H. et. al,. & 2018 & $\begin{array}{l}\text { Arquivo Brasileiro de Medicina Veterinária e } \\
\text { Zootecnia }\end{array}$ & $\begin{array}{l}\text { Relate udder depth to teat } \\
\text { cleaning and contamination } \\
\text { and the health of the } \\
\text { mammary gland in the } \\
\text { robotic milking system. }\end{array}$ & $\begin{array}{l}\text { The most productive cows present more } \\
\text { daily milkings and have a deeper udder } \\
\text { and less effective teat cleaning. }\end{array}$ & $\begin{array}{l}\text { Farms intending to } \\
\text { introduce RMS should } \\
\text { first select and } \\
\text { standardize the udder } \\
\text { shape using cows with } \\
\text { udder depth just above } \\
\text { the hock. The impact } \\
\text { of RMS on teat TBC is } \\
\text { related to pre-milking } \\
\text { teats cleaning } \\
\text { condition, in which the } \\
\text { cows' environment } \\
\text { condition is essential } \\
\text { to obtain milk with } \\
\text { low microbiological } \\
\text { contamination. }\end{array}$ \\
\hline 14 & $\begin{array}{l}\text { Quality of raw } \\
\text { milk from a farm } \\
\text { with automatic } \\
\text { milking systemin } \\
\text { the Czech } \\
\text { republic / Kvalita } \\
\text { mléka z farmy v } \\
\text { České Republice } \\
\text { s } \\
\text { automatizovaným } \\
\text { systémem dojení }\end{array}$ & Janštová, B. et. al., & 2011 & Acta Veterinaria Brno & $\begin{array}{l}\text { Assess the quality of raw } \\
\text { cow's milk from an } \\
\text { automatic milking system. }\end{array}$ & $\begin{array}{l}\text { The mean somatic cell count (SCC) was } \\
221 \pm 46 \cdot 10^{3} \cdot \mathrm{ml}^{-1} \text { (range from } 171 \text { to } \\
237 \cdot 10^{3} \cdot \mathrm{ml}^{-1} \text { ). Somatic cell count } \\
\text { decreases with the increasing level of } \\
\text { zoohygienic conditions, dairy cow } \\
\text { health and welfare and milking } \\
\text { conditions }\end{array}$ & $\begin{array}{l}\text { None of the } \\
\text { determined results } \\
\text { would pose a risk to } \\
\text { the quality of milk. } \\
\text { The automated } \\
\text { milking system thus } \\
\text { seems to be excellent } \\
\text { in terms of milking } \\
\text { and milk hygiene. } \\
\text { Robotic milking also } \\
\text { has the advantages of } \\
\text { promoting good } \\
\text { general health of } \\
\text { animals and animal } \\
\text { welfare and removing } \\
\text { the labour }\end{array}$ \\
\hline 15 & $\begin{array}{l}\text { Milk yield } \\
\text { relative to } \\
\text { supplement } \\
\text { intake and } \\
\text { rumination time } \\
\text { differs by health } \\
\text { status for fresh } \\
\text { cows milked with } \\
\text { automated } \\
\text { systems }\end{array}$ & King, M. T. M. et. al., & 2018 & Journal of dairy science & $\begin{array}{l}\text { Examine associations of } \\
\text { milk yield (per day and } \\
\text { relative to supplement } \\
\text { consumed), AMS } \\
\text { supplement intake, and } \\
\text { rumination time with blood } \\
\text { BHB and SCK status of } \\
\text { dairy cows in early lactation }\end{array}$ & $\begin{array}{l}\text { Milk yield of multiparous cows varied } \\
\text { by health status }(\mathrm{P}<0.001) \text {, such that } \\
\text { cows in SCK (subclinical ketosis) } \\
\text { produced the most milk and OTH (BHB } \\
\text { always }<1.2 \mathrm{mmol} / \mathrm{L} \text {, with a health } \\
\text { disorder) cows were the least } \\
\text { productive. There were differences in } \\
\text { milk yield-to-supplement intake by } \\
\text { health status ( } \mathrm{P}<0.001) \text {. With no } \\
\text { difference in supplement intake } \\
\text { between groups, SCK cows, therefore, } \\
\text { had the highest ratio of milk production } \\
\text { to supplement intake. }\end{array}$ & $\begin{array}{l}\text { Milk production } \\
\text { relative to supplement } \\
\text { intake and rumination } \\
\text { time were positively } \\
\text { associated with blood } \\
\text { BHB and differed by } \\
\text { health status for cows } \\
\text { milked in automated } \\
\text { systems, but we found } \\
\text { no such associations } \\
\text { with supplement } \\
\text { intake. These results } \\
\text { suggest that AMS } \\
\text { settings need to } \\
\text { account for milk } \\
\text { production of cows } \\
\text { during their first } 3 \text { wk } \\
\text { of lactation when } \\
\text { determining } \\
\text { supplemental pellet } \\
\text { allowance }\end{array}$ \\
\hline 16 & $\begin{array}{l}\text { Robotic milking } \\
\text { and its effect on } \\
\text { fertility and cell } \\
\text { counts }\end{array}$ & Kruip, T. A. M. et. al., & 2002 & Journal of dairy science & $\begin{array}{l}\text { Analyze the effect of robotic } \\
\text { milking (RM) on fertility } \\
\text { and somatic cell counts } \\
\text { (SCC) among dairy herds } \\
\text { participating in the national } \\
\text { Dutch milk recording } \\
\text { system. }\end{array}$ & $\begin{array}{l}\text { Significant increase in milk yield is } \\
\text { observed when a change in milking } \\
\text { frequency from } 2 \times \text { to } 3 \times 0 \text { ccurred (from } \\
26.2 \text { to } 31.5 \mathrm{~kg} / \mathrm{d} ; \mathrm{P}<0.001) \text { and when a } \\
\text { change in milking frequency occurred } \\
\text { from } 2 \times \text { to RM (from } 25 \text { to } 27.2 \\
\mathrm{~kg} / \mathrm{d}: \mathrm{P}<0.001 \text { ). Farms with } 3 \times \text { milking } \\
\text { had an average test-day yield higher } \\
\text { than farms with RM and } 2 \times \text {. The mean } \\
\text { SCC was always higher ( } \mathrm{P}<0.05 \text { ) in the } \\
\text { RM group than when those same herds } \\
\text { had been previously milked either at }\end{array}$ & $\begin{array}{l}\text { It is clear that direct } \\
\text { comparisons of effects } \\
\text { of RM and } \\
\text { conventional milking } \\
\text { are difficult because } \\
\text { the systems differ in } \\
\text { more ways than } \\
\text { milking frequency } \\
\text { alone. However, there } \\
\text { are enough data to } \\
\text { expect that with more } \\
\text { experience and }\end{array}$ \\
\hline
\end{tabular}


frequencies of $2 \times$ or $3 \times$. Changing from attention to detail with $2 \times$ to $3 \times$ or vice versa did not all aspects of RM and significantly affect SCC.

improvements in teat cleaning that effects of RM on increasing SCC can be attenuated

\begin{tabular}{|c|c|c|c|c|c|c|c|}
\hline 17 & $\begin{array}{l}\text { Robotic milking } \\
\text { and milk quality: } \\
\text { effects on } \\
\text { bacterial counts, } \\
\text { somatic cell } \\
\text { counts, freezing } \\
\text { point and free } \\
\text { fatty acids }\end{array}$ & De Koning, K. et. al., & 2003 & Italian Journal of Animal Science & $\begin{array}{l}\text { Identify possible risk factors } \\
\text { that affect milk quality on } \\
\text { farms with AM-systems. }\end{array}$ & $\begin{array}{l}\text { For all three countries and for most milk } \\
\text { quality parameters (TPC, BMSCC, FP, } \\
\text { FFA) the milk quality was slightly } \\
\text { negatively affected after introduction of } \\
\text { the AM-system in comparison to the } \\
\text { period before. Differences between the } \\
\text { AM-brands explained } 32 \% \text { percent of } \\
\text { the variation in TPC, } 30 \% \text { was } \\
\text { explained by installation period and } \\
22 \% \text { by farm effect. Regarding } \\
\text { BMSCC, } 56 \% \text { of the variation could be } \\
\text { explained by the farm differences. }\end{array}$ & $\begin{array}{l}\text { The highest levels for } \\
\text { TPC and BMSCC } \\
\text { (bulk milk somatic cell } \\
\text { count) are found in the } \\
\text { first six months after } \\
\text { introduction. After } \\
\text { this period the milk } \\
\text { quality slightly } \\
\text { improves and all farms } \\
\text { more or less stabilize } \\
\text { their levels. } \\
\text { However, the stable } \\
\text { level is still a little } \\
\text { above the } \\
\text { average } \\
\text { conventional of } \\
\text { farms. }\end{array}$ \\
\hline
\end{tabular}

\begin{tabular}{|c|c|c|c|c|c|c|c|}
\hline 18 & $\begin{array}{l}\text { The effect of } \\
\text { concentrate } \\
\text { allocation on } \\
\text { traffic and milk } \\
\text { production of } \\
\text { pasture-based } \\
\text { cows milked by } \\
\text { an automatic } \\
\text { milking system }\end{array}$ & Lessire, F. et. al,. & 2017 & Animal & $\begin{array}{l}\text { Determine the effect of } \\
\text { concentrate allocation on } \\
\text { voluntary cow traffic from } \\
\text { pasture to the robot during } \\
\text { the grazing period, to } \\
\text { highlight the interactions } \\
\text { between grazed pasture and } \\
\text { concentrate allocation in } \\
\text { terms of substitution rate } \\
\text { and the subsequent effect on } \\
\text { average milk yield and } \\
\text { composition. }\end{array}$ & $\begin{array}{l}\text { On average, HC-group (high } \\
\text { concentrate) produced } 1.07 \quad \mathrm{~kg} \\
\text { milk/cow and per day more over the } \\
\text { season, representing } 0.56 \mathrm{~kg} \text { of milk } / \mathrm{kg} \\
\text { concentrate }\end{array}$ & 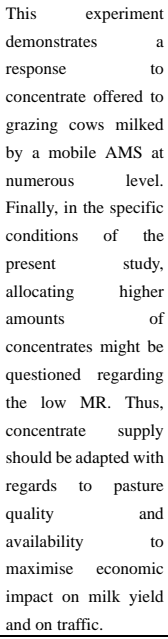 \\
\hline 19 & $\begin{array}{l}\text { Trends in somatic } \\
\text { cell count } \\
\text { deteriorations in } \\
\text { Dutch dairy herds } \\
\text { transitioning to } \\
\text { an automatic } \\
\text { milking system }\end{array}$ & B.H.P. Van den Borne, et. al., & 2020 & Journal of dairy science & $\begin{array}{l}\text { Analyze national trends in } \\
\text { SCC deteriorations of Dutch } \\
\text { dairy herds transitioning } \\
\text { from a CMS to an AMS. }\end{array}$ & $\begin{array}{l}\text { A clear downward trend was observed. } \\
\text { The average monthly BMSCC was } \\
230,000 \text { cells } / \mathrm{mL} \text { in } 2007 \text { and decreased } \\
\text { to } 174,000 \text { cells } / \mathrm{mL} \text { in } 2019 \text {. An } \\
\text { obvious seasonal pattern was also } \\
\text { visible, with BMSCC levels being } \\
\text { higher in the summer period compared } \\
\text { with the winter period. }\end{array}$ & $\begin{array}{l}\text { Using census data } \\
\text { from the Dutch test } \\
\text { day recording, this } \\
\text { study identified that } \\
\text { SCC deteriorations } \\
\text { were common in herds } \\
\text { that transitioned from } \\
\text { a CMS to an AMS. } \\
\text { In the context of } \\
\text { decreasing SCC levels } \\
\text { nation-ally, less strong } \\
\text { SCC deteriorations } \\
\text { were observed during } \\
\text { the } 13 \text {-yr study period. } \\
\text { Farmers and mas-titis } \\
\text { workers should } \\
\text { therefore continue to } \\
\text { pay attention to udder } \\
\text { health when herds } \\
\text { transition to an AMS. } \\
\text { A continued } \\
\text { monitoring of trends } \\
\text { in SCC deteriorations } \\
\text { when herds transition } \\
\text { to an AMS is } \\
\text { recommended to allow } \\
\text { a prompt intervention } \\
\text { if needed }\end{array}$ \\
\hline
\end{tabular}

Articles that considered milk production and quality essential characteristics in their study were presented between 2002 and 2021 (Graph 1). However, we observed that the theme of our investigation was still little explored, especially from 2002 to 2012, when the RMS was not yet popular and underwent some adaptations (Jacobs \& Siegford, 2012). 


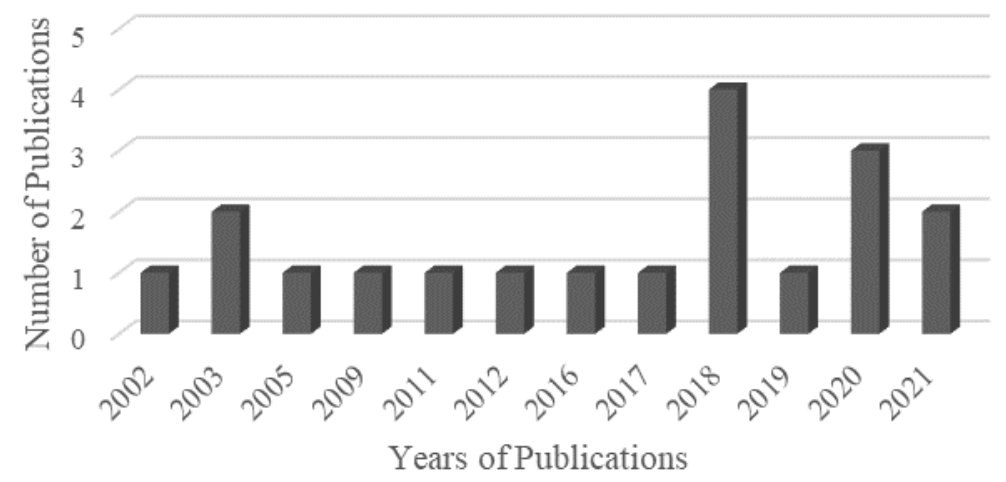

Graph 1. Distribution of publications by years of selected articles

The journals of the selected articles were compared to the number of publications related to the review variables. The Journal of Dairy Science (Graph 2) shows the numerical superiority of articles, representing $47 \%$ of the articles chosen for data extraction. However, this data was not surprising because of the journal's reputation and its purpose of dealing directly with dairy chain issues

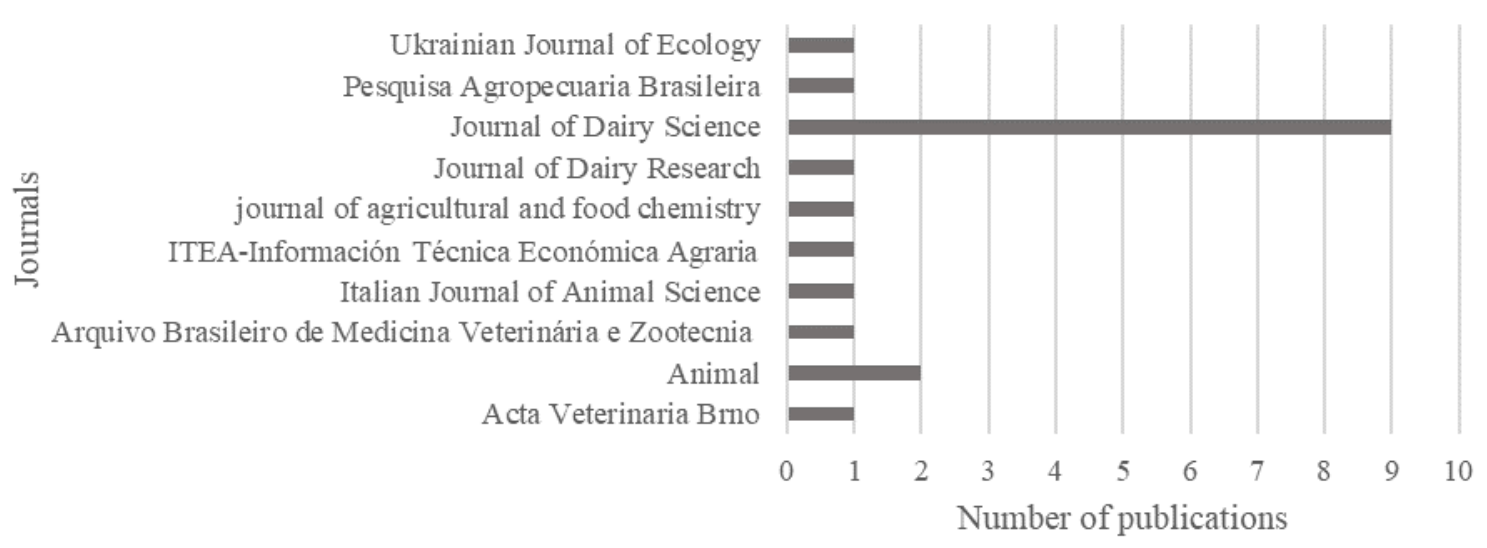

Graph 2. Distribution of journals by publications of selected article

The Descending Hierarchical Classification (DHC) method identified five classes of segments in the vocabularies (Figure 2). The corpus was divided into two sub-corpuses and partitioned to obtain Class 2. In the third stage, there were more partitions, which resulted in other classes. We observed a relationship between metabolic diseases and milk production and animal feeding in the system and the importance of milk management and quality in Classes 3 and 4. 


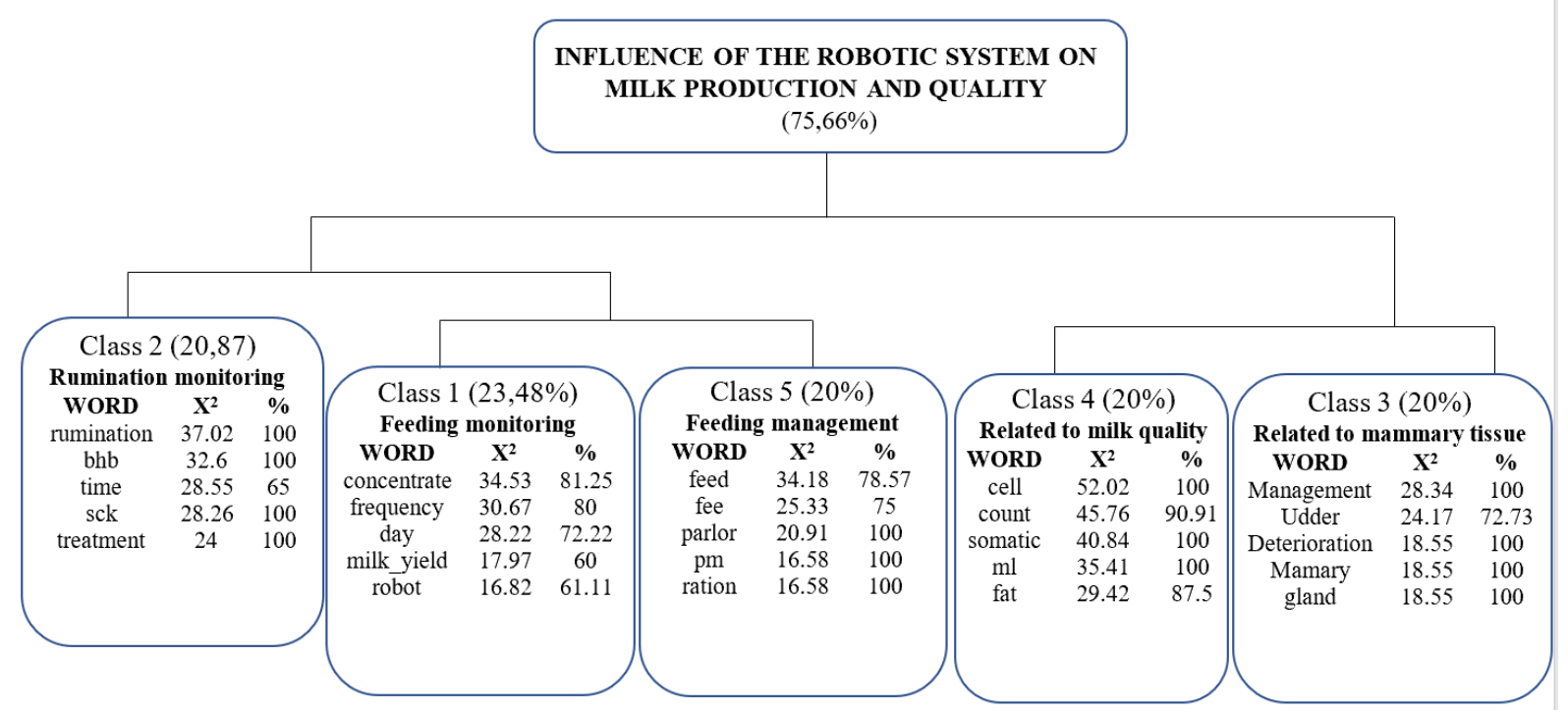

Figure 2. Descending Hierarchical Classification

A direct relationship between the five classes stood out in the similarity analysis. Classes with the terms "milk" and "cow" are entirely related. Still, some subclasses correlate with the class "cow." For example, the words "AMS" (entirely related to "robotic milking") and "farm" farm." On the other hand, we observed the words "health" and "udder" establishing a link with the class "cow," indicating that health is more related to cow and not milk in the selected articles. In the "milk" class, there is a coalition with the milk quality words "somatic," "count," "total" and "cells," indicating a result of a cohesive search in the articles. 


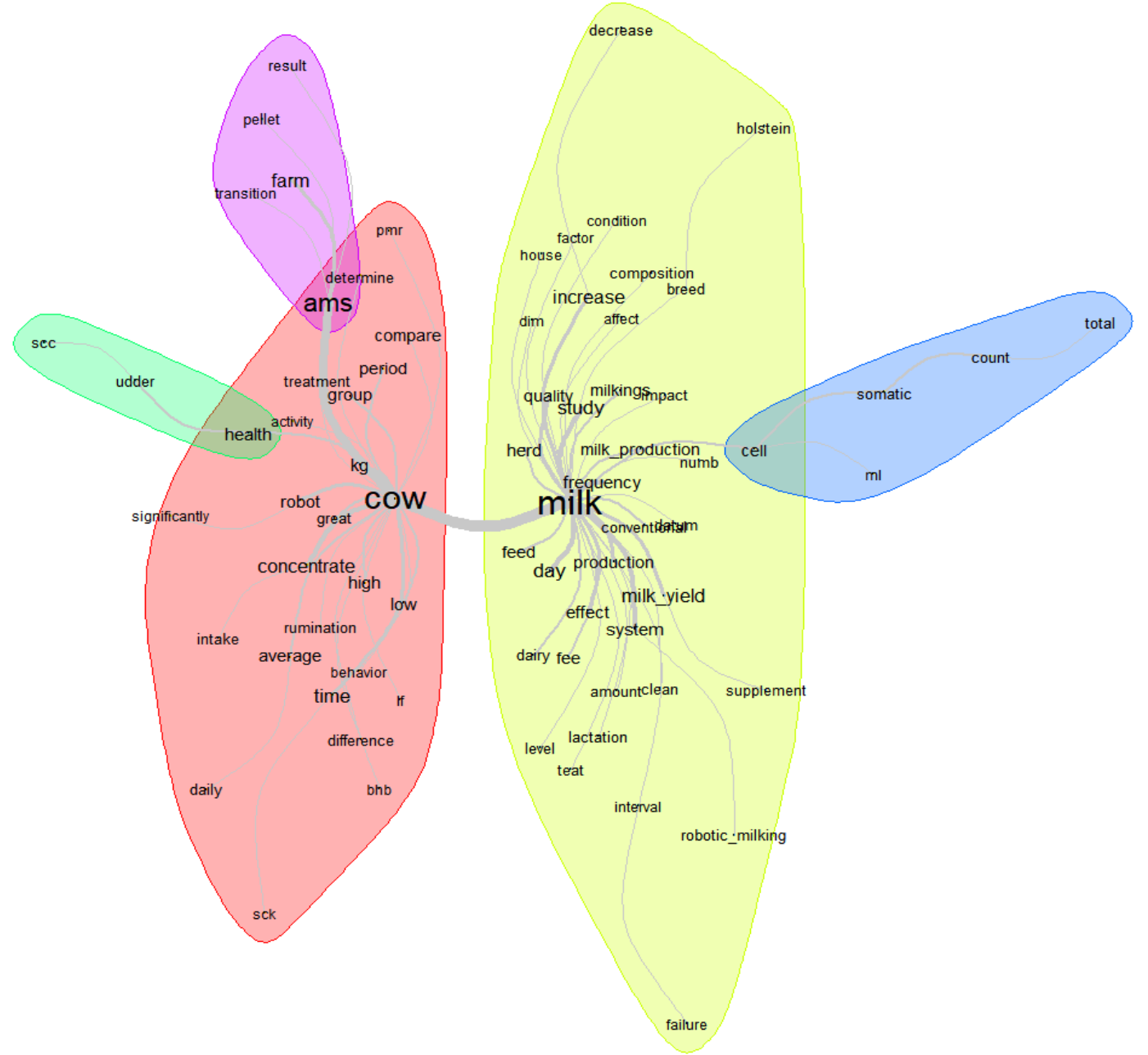

Figure 3. Similarity Analysis Tree

\section{Discussion}

Based on the results of the 19 selected articles, we observed an interaction between the passage of years and an increase in studies on robotic milking. This interaction has been expected since the first commercial RMS was installed on a dairy farm in 1992 (Svennersten-Sjaunja \& Pettersson, 2008). Despite being an innovative technology, the uncertainties of farmers and the low supply of representatives meant that, in the 2000s, the system was accepted in the USA and most European countries (De Koning, 2010).

At that time, research projects observed an increase in somatic cell count and a decrease in quality resulting from the new milking system (Klungel et al., 2000; Vorst, Y. Van der Hogeveen, 2000). This event triggered a warning in farmers that it was a new technology and a different method of conducting the business. Furthermore, this method depends on external factors, such as facility conditions, animal management, and staff rosters (Rossing \& Hogewerf, 1997; Rossing et al., 1997). A new wave of research on RMS began (Jacobs \& Siegford, 2012) from these first complaints and the new challenges in the first decades of the 
2000s, corroborating with the data.

As shown in Graph 2, the Journal of Dairy Science stood out in the number of publications selected by the authors. These data converge because the journal is in the top 10 of the Scopus database in "Animal Science and Zoology" and is based on the CiteScore index, reaching a value of 6.2 (Scopus, 2021).

Considering the h-index by Scimago Journal \& Country Rank, the journal becomes even more relevant in "Animal Science and Zoology" and stands out in the first place of the ranking (Table 3). Using the SRJ index as a reference unit, the Journal of Dairy Science remains in the top 10 rankings (Scimago Journal \& Country Rank, 2021). There was a significant difference compared with the other selected journals. These were not even in the top 20 rankings.

This difference between rankings occurs in the way the indices are calculated. The calculation of CiteScore considers citations from many files such as articles, book chapters, reviews, and data articles. The journal performs the count over four years, dividing by the number of the duplicate files indexed in Scopus and published during the same period (James et al., 2019). The h-index is the reference that indicates the minimum citations referring to the total publications in a certain period, quantifying productivity and scientific impact (Bornmann \& Daniel, 2007).

Table 2. Top $10 \mathrm{~h}$-index journals

\begin{tabular}{|c|c|c|c|c|c|c|c|c|c|}
\hline Rank & Title & SJR & $h$-index & $\begin{array}{l}\text { Total } \\
\text { Docs. } \\
(2020)\end{array}$ & $\begin{array}{c}\text { Total } \\
\text { Docs. } \\
\text { (3years) }\end{array}$ & $\begin{array}{l}\text { Total } \\
\text { Refs. }\end{array}$ & $\begin{array}{c}\text { Total } \\
\text { Cites } \\
\text { (3years) }\end{array}$ & Country & Publisher \\
\hline 1 & $\begin{array}{c}\text { Journal of Dairy } \\
\text { Science }\end{array}$ & 1,483 & 191 & 1042 & 2955 & 47550 & 12522 & United States & Elsevier Ltd. \\
\hline 2 & $\begin{array}{c}\text { Journal of } \\
\text { Experimental } \\
\text { Biology }\end{array}$ & 1,367 & 185 & 608 & 1978 & 17162 & 4857 & $\begin{array}{l}\text { United } \\
\text { Kingdom }\end{array}$ & $\begin{array}{l}\text { Company of } \\
\text { Biologists Ltd }\end{array}$ \\
\hline 3 & $\begin{array}{c}\text { Agriculture, } \\
\text { Ecosystems and } \\
\text { Environment }\end{array}$ & 1,844 & 174 & 316 & 1016 & 20756 & 5842 & Netherlands & Elsevier \\
\hline 4 & Animal Behaviour & 1,261 & 166 & 237 & 845 & 16019 & 2235 & United States & $\begin{array}{l}\text { Academic Press } \\
\text { Inc. }\end{array}$ \\
\hline 5 & $\begin{array}{c}\text { Journal of Animal } \\
\text { Ecology }\end{array}$ & 2,134 & 157 & 253 & 464 & 18722 & 2098 & $\begin{array}{c}\text { United } \\
\text { Kingdom } \\
\end{array}$ & $\begin{array}{c}\text { Wiley-Blackwel } \\
\text { Publishing Ltd }\end{array}$ \\
\hline 6 & $\begin{array}{l}\text { Journal of Animal } \\
\text { Science }\end{array}$ & 0,928 & 156 & 416 & 1468 & 18451 & 3707 & United States & $\begin{array}{c}\text { American } \\
\text { Society of } \\
\text { Animal Science }\end{array}$ \\
\hline 7 & Poultry Science & 1,072 & 141 & 773 & 1804 & 33681 & 6073 & United States & Elsevier Inc. \\
\hline 8 & Theriogenology & 0,816 & 133 & 570 & 1378 & 30541 & 3693 & United States & Elsevier Inc. \\
\hline 9 & $\begin{array}{c}\text { Integrative and } \\
\text { Comparative } \\
\text { Biology }\end{array}$ & 1,328 & 123 & 122 & 380 & 9160 & 1114 & $\begin{array}{l}\text { United } \\
\text { Kingdom }\end{array}$ & $\begin{array}{c}\text { Oxford } \\
\text { University Press }\end{array}$ \\
\hline 10 & $\begin{array}{l}\text { Behavioral } \\
\text { Ecology and } \\
\text { Sociobiology }\end{array}$ & 1,203 & 120 & 152 & 538 & 10919 & 1373 & Germany & Springer Verlag \\
\hline
\end{tabular}

Within the DHC (Figure 2), the sub-corpus refers to classes 1, 2, and 5 instead of classes 3 and 4 , representing $64.35 \%$ of the total textual corpus, whereas classes 3 and 4 represented $35.65 \%$ of the results. The first set of data signaled the importance of the studied variables. This aspect can be observed through an analysis of the selected terms. 
Through the analysis of Class 2, the relationship between metabolic diseases and animal rumination became clear. Milk production and rumination time are responsive variables to a cow's health status. However, cows with subclinical ketosis achieved low rumination rates in an RMS, although they produced the highest rumination rates (King et al., 2018). This may be related to the high production rates of the herd, indicating the need for energy supplementation in animals fed partial mixed rations (PMR). Regarding this class, the variations in beta-hydroxybutyrate (BHB) in the system did not vary significantly in the evaluated studies.

Classes 1 and 5 complement each other. Animal feeding has attracted the attention of researchers. The system's users know the use of the concentrate to acquire higher visitation rates for the robot. However, some studies have reported that the gains in production by using this technique are limited despite maintaining a constant dry matter intake (Lessire et al., 2017; Schwanke et al., 2019). Some researchers even suggest using pellets with neutral detergent fibers and high degradability rates in the robot to increase visits without affecting production and milk composition (Halachmi et al., 2009). However, these results may be controversial with respect to milk production. We observed more occurrences of animals with mastitis in the robotic system than in conventional milking, leading to decreased production rates (Stergiadis et al., 2012)

Another essential factor in Classes 1 and 5 is the passage rate. It is essential to adapt a herd to voluntary milking, and this indicator is usually related to animal productivity (Borshch et al., 2020). Although voluntary milking can benefit animals, a higher visit rate was observed between 8 a.m. and 11 a.m. and between 3 p.m. and 6 p.m. This can be explained using the forced milking technique (Wagner-Storch \& Palmer, 2003). Forcing animals to go through milking and increasing their frequency may decrease milk flow and increase milking time, milk production, and milk composition. Locomotion problems, lactation stage, and the production rate of each cow are also factors that influence visit rates (King et al., 2017; Córdova et al., 2018a).

In the second sub-corpus, Classes 3 and 4, the selected words were correlated with milk quality. Many studies have correlated the increase in somatic cell counts with the entry of animals into RMSs (Kruip et al., 2002; Avilez Ruiz et al., 2021; Van den Borne et al., 2021). However, some researchers have suggested that this high counting rate decreases after six months of herd adaptation (De Koning et al., 2003). The increase in SCC may be caused by failures in the fixation of teats, which can reach up to $7 \%$ of all milkings (Bach \& Busto, 2005). Although there is an increase in SCC, there is also an increase in the milk fat of animals in RMS (Janštová et al., 2011; Avilez Ruiz et al., 2021; Matson et al., 2021).

An increase in SCC may also result from inadequate teat sanitation (Van den Borne et al., 2021). Cows with shallow and small udders are not recommended for robotic milking. Therefore, farms installing the system should select animals with greater udder depth to achieve better mammary gland health in this system (Córdova et al., 2018b; Tse et al., 2018).

Nevertheless, RMS is highly effective in terms of milk hygiene. Samples from cooled tanks were collected from facilities with an automated milking system, and the total bacterial count 
was below the minimum evaluation value (Janštová et al., 2011).

The similarity analysis unifies the terms "cow" and "milk," organizing a perception of the system. The term "AMS" (automatic milking system) is not directly associated with the word "milk." This indicates that milk production and quality are not related to the milking system but the animal. Thus, the system directly influences animal health and feeding (Figure 3). Milk production and somatic cell count are directly associated with "milk" and "cow." Thus, we can observe a link between animal welfare and better sanitary conditions in the final product.

\section{Conclusion}

This study demonstrated the influence of a robotic system on milk production and quality. Analyzing the articles lexicographically, we can observe the similarity of their terms and glimpse at a new vision of the system and its variables for future decision making. SCC has significant similarities with "milk" and "cow." Therefore, farmers should act directly on the herd's health to modify the rates of somatic cells in milk, rather than modifying the milking system. As RMS is directly related to feeding, before deciding to change the property system, farmers should consider the nutritional supply of the herd

\section{References}

Avilez Ruiz, J. P., Meyer, P., \& Meyer, J. L. (2021). Comparación del sistema de ordeño convencional y robotizado para los parámetros de composición y calidad de leche, en sistema a pastoreo. Informacion Tecnica Economica Agraria, 117, 162-172.

https://doi.org/10.12706/itea.2020.018

Bach, A., \& Busto, I. (2005). Effects on milk yield of milking interval regularity and teat cup attachment failures with robotic milking systems. Journal of Dairy Research, 72, 101-106. https://doi.org/10.1017/S0022029904000585

Bornmann, L., \& Daniel, H. D. (2007). What do we know about the h index? Journal of the American Society for Information Science and Technology, 58, 1381-1385. https://doi.org/10.1002/asi.20609

Borshch, O. O., Gutyj, B. V., Sobolev, O. I., Borshch, O. V., Ruban, S. Y., Bilkevich, V. V., \& Dutka, V. R. et al. (2020). Adaptation strategy of different cow genotypes to the voluntary milking system. Ukrainian Journal of Ecology, 10, 145-150.

https://doi.org/10.15421/2020_23

Cogato, A., Brščić, M., Guo, H., Marinello, F., \& Pezzuolo, A. (2021). Challenges and tendencies of automatic milking systems (AMS): A 20-years systematic review of literature and patents. Animals, 11, 1-21. https://doi.org/10.3390/ani11020356

Córdova, H. A., Cardozo, L. L., Alessio, D. R. M., \& Neto, A. T. (2018b). Influence of udder depth on cleaning teats and health of the mammary gland in robotic milking. Arquivo Brasileiro de Medicina Veterinaria e Zootecnia, 70, 1443-1452.

Córdova, H. A., Cardozo, L. L., Alessio, D. R. M., \& Neto, A. T. (2020). Behaviour of 
holstein cows in robotic milking. Arquivo Brasileiro de Medicina Veterinaria e Zootecnia, 72, 263-272. https://doi.org/10.1590/1678-4162-10057

Córdova, H. de A., Alessio, D. R. M., Cardozo, L. L., \& Neto, A. T. (2018a). Impact of the factors of animal production and welfare on robotic milking frequency. Pesquisa Agropecuaria Brasileira, 53, 238-246. https://doi.org/10.1590/s0100-204x2018000200013

De Koning, C. J. A. M. (Kees). (2010). Automatic Milking - Common Practice on Dairy Farms. The First North American Conference on Precision Dairy Management, 16.

De Koning, K., Slaghuis, B., \& Van der Vorst, Y. (2003). Robotic milking and milk quality: effects on bacterial counts, somatic cell counts, freezing point and free fatty acids. Italian Journal of Animal Science, 2, 291-299. https://doi.org/10.4081/ijas.2003.291

Filho, L. M. S., Lopes, M. A., Brito, S. C., Rossi, G., Prof, L. C., \& Barbari, M. (2020). Robotic milking of dairy cows: A review. Semina: Ciencias Agrarias, 41, 2833-2849. https://doi.org/10.5433/1679-0359.2020v41n6p2833

Halachmi, I., Shoshani, E., Solomon, R., Maltz, E., \& Miron, J. (2009). Feeding soyhulls to high-yielding dairy cows increased milk production, but not milking frequency, in an automatic milking system. Journal of Dairy Science, 92, 2317-2325. https://doi.org/10.3168/jds.2007-0958

Hogenboom, J. A., Pellegrino, L., Sandrucci, A., Rosi, V., \& Incecco, P. D. (2019). Invited review : Hygienic quality, composition, and technological performance of raw milk obtained by robotic milking of cows. Journal of Dairy Science, 102, 7640-7654. https://doi.org/10.3168/jds.2018-16013

Hovinen, M., \& Pyörälä, S. (2011). Invited review: Udder health of dairy cows in automatic milking. Journal of Dairy Science, 94, 547-562. https://doi.org/10.3168/jds.2010-3556

Jacobs, J. A., \& Siegford, J. M. (2012). Invited review: The impact of automatic milking systems on dairy cow management, behavior, health, and welfare. Journal of Dairy Science, 95, 2227-2247. https://doi.org/10.3168/jds.2011-4943

James, C., Colledge, L., Meester, W., Azoulay, N., \& Plume, A. (2019). CiteScore metrics: Creating journal metrics from the Scopus citation index. Learned Publishing, 32, 367-374. https://doi.org/10.1002/leap.1246

Janštová, B., Dračková, M., Dlesková, K., Cupáková, Š., Necidová, L., Navrátilová, P. \& Vorlová, L. (2011). Quality of raw milk from a farm with automatic milking system in the Czech republic. Acta Veterinaria Brno, 80, 207-214.

https://doi.org/10.2754/avb201180020207

King, M. T. M., \& DeVries, T. J. (2018). Graduate Student Literature Review: Detecting health disorders using data from automatic milking systems and associated technologies. Journal of Dairy Science, 101, 8605-8614. https://doi.org/10.3168/jds.2018-14521

King, M. T. M., LeBlanc, S. J., Pajor, E. A., \& DeVries, T. J. (2017). Cow-level associations 
of lameness, behavior, and milk yield of cows milked in automated systems. Journal of Dairy Science, 100, 4818-4828. https://doi.org/10.3168/jds.2016-12281

King, M. T. M., Sparkman, K. J., LeBlanc, S. J., \& DeVries, T. J. (2018). Milk yield relative to supplement intake and rumination time differs by health status for fresh cows milked with automated systems. Journal of Dairy Science, 101, 10168-10176. https://doi.org/10.3168/jds.2018-14671

Kitchenham, B., Pearl Brereton, O., Budgen, D., Turner, M., Bailey, J., \& Linkman, S. (2009). Systematic literature reviews in software engineering - A systematic literature review. Information and Software Technology, 51, 7-15. https://doi.org/10.1016/j.infsof.2008.09.009

Klungel, G. H., Slaghuis, B. A., \& Hogeveen, H. (2000). The effect of the introduction of automatic milking systems on milk quality. Journal of Dairy Science, 83, 1998-2003. https://doi.org/10.3168/jds.S0022-0302(00)75077-6

Koutsos, T. M., Menexes, G. C., \& Dordas, C. A. (2019). An efficient framework for conducting systematic literature reviews in agricultural sciences. Science of the Total Environment, 682, 106-117. https://doi.org/10.1016/j.scitotenv.2019.04.354

Kruip, T. A. M., Morice, H., Robert, M., \& Ouweltjes, W. (2002). Robotic milking and its effect on fertility and cell counts. Journal of Dairy Science, 85, 2576-2581. https://doi.org/10.3168/jds.S0022-0302(02)74341-5

Lessire, F., Froidmont, E., Shortall, J., Hornick, J. L., \& Dufrasne, I. (2017). The effect of concentrate allocation on traf fi c and milk production of pasture-based cows milked by an automatic milking system. Animal, The International Journal of Animal Biosciences, 11, 2061-2069. https://doi.org/10.1017/S1751731117000659

Masía, F. M., Lyons, N. A., Piccardi, M., Balzarini, M., Hovey, R. C., \& Garcia, S. C. (2020). Modeling variability of the lactation curves of cows in automated milking systems. Journal of Dairy Science, 103, 8189-8196. https://doi.org/10.3168/jds.2019-17962

Matson, R. D., King, M. T. M., Duffield, T. F., Santschi, D. E., Orsel, K., Pajor, E. A., \& Penner, G. B. et al (2021). Benchmarking of farms with automated milking systems in Canada and associations with milk production and quality. Journal of Dairy Science, 104, 7971-7983. https://doi.org/10.3168/jds.2020-20065

Moore, S. M., King, M. T. M., Carpenter, A. J., \& DeVries, T. J. (2020). Behavior, health, and productivity of early-lactation dairy cows supplemented with molasses in automated milking systems. Journal of Dairy Science, 103, 10506-10518.

https://doi.org/10.3168/jds.2020-18649

Rodenburg, J. (2017). Robotic milking: Technology, farm design, and effects on work flow. Journal of Dairy Science, 100, 7729-7738. https://doi.org/10.3168/jds.2016-11715

Rossing, W., \& Hogewerf, P. H. (1997). State of the art of automatic milking systems. Computers and Electronics in Agriculture, 17, 1-17.

https://doi.org/10.1016/S0168-1699(96)01229-X 
Rossing, W., Hogewerf, P. H., Ipema, A. H., Lauwere, C. C. K. D., \& De Koning, C. J. A. M. (1997). Robotic milking in dairy farming. Netherlands Journal of Agricultural Science, 45, 15-31. https://doi.org/10.18174/njas.v45i1.523

Schwanke, A. J., Dancy, K. M., Didry, T., Penner, G. B., \& DeVries, T. J. (2019). Effects of concentrate location on the behavior and production of dairy cows milked in a free-traffic automated milking system. Journal of Dairy Science, 102, 9827-9841.

https://doi.org/10.3168/jds.2019-16756

Scimago Journal \& Country Rank. (2021). Journal Rankings on Animal Science and Zoology. Retrieved from

https://www.scimagojr.com/journalrank.php?category=1103\&area=1100\&order=h\&ord=desc \&type $=\mathrm{j}$

Scopus. (2021). Scopus Source. Retrieved from https://www.scopus.com/sources.uri

Stelwagen, K., \& Lacy-Hulbert, S. (1996). Effect of milking frequency on milk somatic cell count characteristics and mammary secretory cell damage in cows. American Journal of Veterinary Research, 57, 902-905.

Stergiadis, S., Leifert, C., Seal, C. J., Eyre, M. D., Nielsen, J. H., Larsen, M. K., \& Slots, T. et al. (2012). Effect of feeding intensity and milking system on nutritionally relevant milk components in dairy farming systems in the north east of England. Journal of Agricultural and Food Chemistry, 60, 7270-7281. https://doi.org/10.1021/jf301053b

Svennersten-Sjaunja, K. M., \& Pettersson, G. (2008). Pros and cons of automatic milking in Europe. Journal of animal science, 86, 37-46. https://doi.org/10.2527/jas.2007-0527

Tse, C., Barkema, H. W., DeVries, T. J., Rushen, J., \& Pajor, E. A. (2018). Impact of automatic milking systems on dairy cattle producers' reports of milking labour management, milk production and milk quality. Animal, 12, 2649-2656.

https://doi.org/10.1017/S1751731118000654

Van den Borne, B. H. P., Van Grinsven, N. J. M., \& Hogeveen, H. (2021). Trends in somatic cell count deteriorations in Dutch dairy herds transitioning to an automatic milking system. Journal of Dairy Science, 104, 6039-6050. https://doi.org/10.3168/jds.2020-19589

Vorst, Y., \& Van der Hogeveen, H. (2000). Automatic milking systems and milk quality in the Netherlands. In Hogeveen, H. \& Meijering, A. (Eds.), Robotic milking: Proceedings of the Internacional Symposium (pp. 73-82). Lelystad: Wageningen Pers.

Wagner-Storch, A. M., \& Palmer, R. W. (2003). Feeding behavior, milking behavior, and milk yields of cows milked in a parlor versus an automatic milking system. Journal of Dairy Science, 86, 1494-1502. https://doi.org/10.3168/jds.S0022-0302(03)73735-7 
List of abbreviations and acronyms

\begin{tabular}{|l|l|}
\hline Abbreviation & Explanation \\
\hline RMS & Robotic Milking System \\
\hline SCC & Somatic Cell Count \\
\hline TBC & Total Bacterial Count \\
\hline DHC & Descending Hierarchical Classification \\
\hline SCK & Subclinical Ketosis \\
\hline BHB & Beta-hydroxybutyrate \\
\hline PVO & Population Variable Outcome \\
\hline PMR & Partial Mixed Ration \\
\hline
\end{tabular}

\section{Copyright Disclaimer}

Copyright for this article is retained by the author(s), with first publication rights granted to the journal.

This is an open-access article distributed under the terms and conditions of the Creative Commons Attribution license (http://creativecommons.org/licenses/by/4.0/). 